\title{
HOST SUITABILITY OF SOME MEDICINAL PLANTS TO Meloidogyne incognita INFECTION UNDER GREENHOUSE CONDITIONS
}

\author{
El-Sherif, A. G. * ; A. R. Refaei* ; M. E. El-Naggar ** and \\ Mayada M. Hefny** \\ *Nematology Res. Unit, Agric. Zool. Dept, Fac. of Agric., Mansoura Univ. \\ Dkahlia. Egypt. \\ **Plant protection Inst., ARC, Dokki, Giza , Egypt.
}

\section{ABSTARCT}

The host suitability of ten medicinal plant species i.e. carnation, celery, coriander, dill, geranium, peppermint, periwinkle, rose geranium, thorn apple and thyme to Meloidogyne incognita infection indicated that none of the tested plant species was immune and the incidence varied from plant species to another. Their host category was determined through the relationship between host plant growth response (\% reduction of total plant fresh weight) or gall index and nematode reproduction factor (RF). Carnation and thyme were rated as highly susceptible (HS) or susceptible (S) hosts, since their plant growth parameters were highly affected along with reproduction factor $>1$. Rose geranium was rated as moderately intolerant (IT) or moderately resistant (MR), since its plant growth character was moderately affected along with reproduction factor $<1$. Geranium was rated as fairly resistant (FR) or (MR), since its plant growth criterion was moderately affected with reproduction factor $>1$. Dill, celery, coriander, thorn apple and periwinkle were classified as resistant $(R)$ or moderately resistant (MR)hosts, since their plant growth were not affected with reproduction factors $<1$, depending upon the host suitability designations used.

Keywords : Host suitability, ten medicinal plants, Meloidogyne incognita, reproduction factor (RF)

\section{INTRODUCTION}

Root-knot nematodes (Meloidogyne spp.) are one of the most wide spread and damaging agricultural pests in the world causing an estimated US $\$ 100$ billion loss/ year worldwide (Oka et al ., 2000). They were widely distributed in the cultivated areas of Egypt causing remarkable crop losses, particularly with eggplant, pepper yields. However, the host status of several plant species has remained unexplored. Resistant cultivars may provide an effective, economical and environmentally safe method for managing nematodes. The current availability and/or use of resistant cultivars and root stocks for nematode management reflects the success of research efforts in identifying and evaluating resistance sources, incorporating them into commercially acceptable crop selections, and implementing them into management programs (Ferris, 1992). The knowledge of host suitability of medicinal plants to root-knot nematodes is necessary to predict the potential effect on plant production and also the influence of each plant on nematode populations with regard to increasing or decreasing the risk of root-knot nematode on susceptible crops to be cultivated after plants. 
The objective of the present investigation was to study the host suitability of ten medicinal plant species, to the root knot nematode, Meloidogyne incognita infection under green house conditions $\left(28 \pm 3^{\circ} \mathrm{C}\right)$.

\section{MATERIALS AND METHODS}

A green house experiment was conducted in order to evaluate ten medicinal plant species namely: carnation, celery, coriander, dill, geranium, peppermint, periwinkle, rose geranium, thorn apple and thyme for their susceptibility or resistance to the root-knot nematode, $M$. incognita infection. Sixty plastic pots $10 \mathrm{~cm}$-d filled with $900 \mathrm{~g}$ steam- sterilized sandy $10 a \mathrm{~m}$ soil $(1: 1)(v: v)$ were used in this experiment, where thirty six pots were planted with 3 seeds from each of the following plants, carnation, celery, coriander, dill, periwinkle and thorn apple and thinned to one plant often twenty five days from planting. In the mean time, the other twenty four pots were separately planted with cutting of each of geranium, peppermint, rose geranium and thyme (one cutting/pot).Six pots were used for each plant species, where three of them were inoculated with $1000 \mathrm{j} 2$ of $M$.incognita one month after planting, while the other three pots were left free of nematode inoculum to serve as control (CK). Plants were allowed to grow for 45 days at $28 \pm 3^{\circ} \mathrm{C}$.At the end of experiment, plants were uprooted and roots were washed from adhering soil. Data dealing with length and fresh weight of shoot and root and shoot dry weight were measured and recorded. Infected roots were stained in lactic acid fuchsin (Byrd et al., 1983) and determined the number of developmental stages, females, eggmasses and galls under stereomicroscope and recorded. Soil of each pot were processed for nematode extraction by sieving and modified Baermann-Technique (Goodey, 1957). Root galling (RGI) as well as egg masses (El) were rated on a scale of 0 to 5 where $0=$ no galls or egg masses, $1=1-2,2=3-10,3=11-30,4=31$ $100,5=$ more than 100 galls or egg -masses per root system (Taylor and Sasser, 1978). Host susceptibility was based on the relationship between reproduction factor (RF) and indices of galls (Canto-Saenz, 1983) or plant growth response (\% reduction of total plant fresh weight) and nematode reproduction factor (RF). Data were subjected to analysis of variance (ANOVA) (Gamez and Gomez, 1984), followed by Duncan's multiple range test to compare means (Duncan,1955).

\section{RESULTS AND DISCUSSION}

Results of growth response of ten medicinal plants to $M$. incognita infection are presented in Table (1) and Figure (1). In general, the growth of most tested plants were slightly affected by nematode infection, except of thyme and carnation, since their reduction percentage values were 47.1 and 60.5\%: and 35.2 and $44.0 \%$ for total plant fresh weight and shoot dry weight, respectively comparing to nematode alone, (Table 1 \& Fig. 1). Among the tested plants, geranium, coriander and rose geranium exhibited moderately decline in both total plant growth fresh weight and shoot dry weight with values of (17.2and $6.9 \%, 15.4$ and $10.0 \%$ and 10.8 and $18.9 \%$, respectively, comparing to nematode alone. The effect of most tested medicinal plants against $M$. incognita infection indicated that they have nematicidal properties, 
except that of carnation, thyme which were classified as highly susceptible hosts.

The screening of medicinal plant species revealed that none of the tested plant species was immune to root-knot nematode $M$. incognita infection, though the incidence varied from plant species to another. Evaluation medicinal plant species differed greatly in their abilities to support M. incognita populations (Table 3). Of the screened ten plant species, thyme exhibited the highest rate of nematode reproduction $(R F=1.1)$ followed by carnation $(R F=1.01)$, respectively. Moreover, number of galls and egg masses recovered from roots differed among tested plant species. Likewise, the great number of galls was recovered on thyme (150) and carnation (100) with root gall indices (RGI) 5and 5, respectively. Similar trend was noticed with number of egg masses for the same plant species with egg masses indices 5and 5, respectively.

Host category of the tested medicinal plant species was decided based on the relationship between either host plant growth responses $(\%$ reduction of total plant fresh weight or gall index and nematode reduction factor (RF). Carnation and thyme were rated as highly susceptible (HS) or susceptible (S) hosts, since their plant growth parameters were highly affected along with reproduction factor $>1$. Rose geranium was rated as moderately intolerant (IT) or moderately resistant (MR), since its plant growth was moderately affected along with reproduction factor $<1$. Geranium was rated as fairly resistant (FR) or moderately resistant (MR), since its plant growth parameter was moderately affected with reproduction factor $>1$. Dill, celery, coriander, thorn apple and periwinkle were classified as resistant hosts $(R)$ or $(M R)$, since their plant growth were not affected with reproduction factors $<1$, depending upon the host suitability designations followed (Table 3)

Apparently, results of the present work firstly revealed that the suitability of the tested ten medicinal and aromatic plant species to nematode infection where none of them was immune and the incidence varied from plant species to another. Obviously carnation and thyme were rated as highly susceptible hosts (HS) or (S) based on the highly affected of plant growth with RF>1, Rosa germanium was rated as a moderately intolerant (IT) or $(\mathrm{MR})$, where the moderately affected of plant growth with RF $<1$. Geranium was rated as fairly resistance (FR) or (MR), where the moderately affected of plant growth with RF $>1$. Dill , celery, coriander, thorn apple and periwinkle were classified as resistant hosts $(R)$ where the unaffected plant growth with $\mathrm{RF}<1$. These findings disagreed with those reported by Wang and Mscorley (2005) in respect to white dill that was less susceptible than snapdragon. The present results are in agreement with those reported by El-Derriny (2009) who stated that , mountain thyme, (Plectranthus amboinicus) and carnation, (Dianthus caryophyllus), were found to be either susceptible or highly susceptible to $M$. incognita, where the reproduction factor was more than one to 5 times, resulting in great decrease to plant growth, and that of Fernandez et al., (1991); Walker et al., (1994) Cho et al., (1996); Johnson et al., (2003) and Khanna and Jyoti, (2004) who recorded the susceptibility of carnation to $M$. incognita. 


\section{El-Sherif, A. G. et al.}

1 


\begin{tabular}{|ll}
\hline Red \% whole plant fresh weight $\quad \square$ Red \% shoot dry weight \\
\hline
\end{tabular}

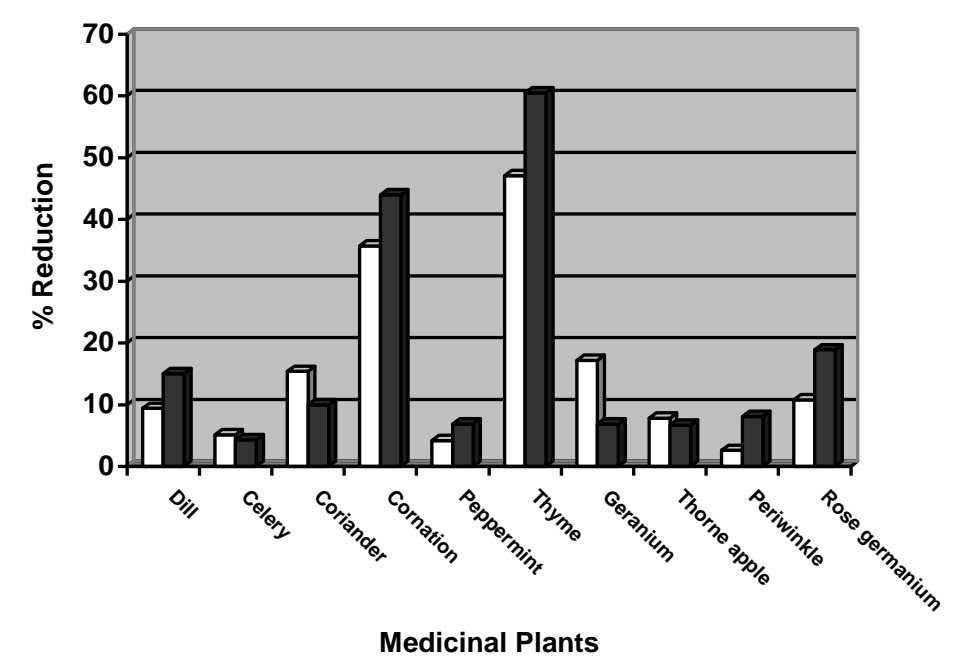

Fig.(1): Reduction percentage of whole plant and shoot dry weights of ten medicinal plant species as influenced by Meloidogyne incognita infection under greenhouse conditions $\left(28 \pm 3^{\circ} \mathrm{C}\right)$.

Table (2): Development and rate of Meloidogyne incognita reproduction on ten medicinal plant species under greenhouse conditions $(28 \pm 3 \circ \mathrm{C})$ :.

\begin{tabular}{|c|c|c|c|c|c|c|c|c|c|}
\hline \multirow{3}{*}{$\begin{array}{c}\text { Treatments } \\
\text { Plant species }\end{array}$} & \multicolumn{4}{|c|}{${ }^{\star}$ Nematode population in } & \multirow{3}{*}{$\begin{array}{l}\underset{\boldsymbol{u}}{\boldsymbol{\alpha}} \\
* \\
*\end{array}$} & \multirow{3}{*}{ 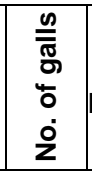 } & \multirow{3}{*}{ RGI } & \multirow{3}{*}{ 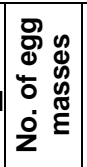 } & \multirow{3}{*}{$\begin{array}{c}\star \star \star \star \\
\text { EI }\end{array}$} \\
\hline & \multirow[b]{2}{*}{ Soil/pot } & \multicolumn{2}{|c|}{ Root } & \multirow[b]{2}{*}{$\begin{array}{c}\text { Total } \\
\text { (Pf) }\end{array}$} & & & & & \\
\hline & & $\begin{array}{c}\text { Develop. } \\
\text { stages }\end{array}$ & Females & & & & & & \\
\hline Carnation & $860.0 \mathrm{a}$ & 20.0 be & $125.0 \mathrm{~cd}$ & 1005 & 1.01 & $100 \mathrm{bc}$ & 5 & $120 \mathrm{~b}$ & 5 \\
\hline Celery & $450 \mathrm{~d}$ & $29.0 \mathrm{e}$ & $14.0 \mathrm{~cd}$ & 493 & 0.49 & $15 \mathrm{bc}$ & 3 & $10 b$ & 2 \\
\hline Coriander & $450 \mathrm{~d}$ & $25.0 \mathrm{~b}$ & $16.0 \mathrm{c}$ & 491 & 0.49 & $15 b c$ & 3 & $10 \mathrm{~b}$ & 2 \\
\hline Dill & $612 \mathrm{c}$ & $10.3 \mathrm{de}$ & $20.0 \mathrm{c}$ & 642.3 & 0.64 & $19 b c$ & 3 & $10 \mathrm{~b}$ & 2 \\
\hline Geranium & $604 \mathrm{c}$ & $12.0 \mathrm{cde}$ & $14.0 \mathrm{~cd}$ & 630 & 0.63 & $16 \mathrm{bc}$ & 3 & $12 \mathrm{~b}$ & 3 \\
\hline Peppermint & 500 ed & 15.0 cde & $2.0 \mathrm{e}$ & 517 & 0.52 & $1.0 \mathrm{~d}$ & 1 & $1.0 \mathrm{c}$ & 1 \\
\hline Periwinkle & $98 \mathrm{e}$ & $20.0 \mathrm{bc}$ & $12.0 \mathrm{~cd}$ & 130 & 0.13 & $18 \mathrm{bc}$ & 3 & $10 \mathrm{~b}$ & 2 \\
\hline Rose geranium & $415 d$ & $10.0 \mathrm{de}$ & $13.0 \mathrm{~cd}$ & 438 & 0.44 & $16 \mathrm{bc}$ & 3 & $11 \mathrm{~b}$ & 3 \\
\hline Thorne apple & $80 \mathrm{e}$ & 18.0 bed & $10.0 \mathrm{~d}$ & 108.0 & 0.11 & $12.0 \mathrm{c}$ & 3 & $9.3 b$ & 2 \\
\hline Thyme & $800 \mathrm{~b}$ & $100.0 \mathrm{a}$ & $155.0 \mathrm{a}$ & 1055 & $1 . .1$ & $150.0 \mathrm{a}$ & 5 & $140.0 \mathrm{a}$ & 5 \\
\hline
\end{tabular}

$\mathrm{Pi}=1000 \mathrm{~J} 2$ of $M$. Incognita

${ }^{*}$ Reproduction factor $(\mathbf{R f})=$ Final population $(\mathrm{Pf}) /$ intial population $(\mathrm{Pi})$.

${ }^{\star *}$ Each value is a mean of three replicates.

Means in each column followed by the same letter(s) did not differ at $p<0.05$ according to Duncan's multiple-range test. 
El-Sherif, A. G. et al.

Table (3): Host susceptibility of ten medicinal plant species to Meloidogyne incognita infection under greenhouse conditions $\left(28 \pm 3^{\circ} \mathrm{C}\right)$.

\begin{tabular}{|c|c|c|c|c|c|c|}
\hline Plant Species & $\mid \begin{array}{c}\text { Total plant } \\
\text { Fresh } \\
\text { weight } \\
\text { Red. } \\
\%\end{array}$ & 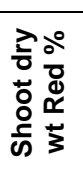 & $\stackrel{u}{\boldsymbol{\alpha}}$ & ত্ম & 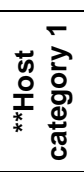 & 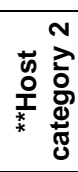 \\
\hline Carnation & 35.2 & 44 & 1.01 & 5 & $\mathrm{HS}$ & $\mathrm{S}$ \\
\hline Celery & 5.1 & 4.3 & 0.0 .49 & 3 & $\mathrm{R}$ & MR \\
\hline Coriander & 15.4 & 10.0 & 0.49 & 3 & $\mathrm{R}$ & MR \\
\hline Dill & 9.4 & 15.0 & 0.64 & 3 & $\mathrm{R}$ & MR \\
\hline Geranium & 17.2 & 6.9 & 0.63 & 3 & FR & MR \\
\hline Peppermint & 4.2 & 6.9 & 0.52 & 1 & $\mathrm{R}$ & $\mathrm{R}$ \\
\hline Periwinkle & 2.6 & 8.1 & 0.13 & 3 & $\mathrm{R}$ & MR \\
\hline Rose geranium & 10.8 & 18.9 & 0.44 & 3 & IT & MR \\
\hline Thorne apple & 7.8 & 6.7 & 0.11 & 3 & $\mathrm{R}$ & MR \\
\hline Thyme & 47.1 & 60.5 & $1 . .1$ & 5 & $\mathrm{HS}$ & $\mathrm{S}$ \\
\hline
\end{tabular}

*Each value is a mean of three replicates. ${ }^{*}$ *Host category (1) based on the relationship between host response and $\mathbf{R}$ factor as follows:

$0-10 \%$ reduction in plant growth; $R F=0$ Highly Resistant (HR)

$$
R F<1 \text { Resistant (R) }
$$

$R F>1$ Tolerant $(T)$.

$11-30 \%$ reduction in plant growth; $R F<1$ Fairly Resistant (FR)

$30 \%>$ reduction in plant growth; $R F<1$ Intolerant (IT)

RF> 1 Susceptible (S).

$(R G I \leq 2 \& R \leq 1)$ resistant (R), (RGI $\leq 2 \& R>1$ ) tolerant (T), (RGI > $2 \& R \leq 1)$ Moderately Resistant (MR) and (RGI > $2 \& R>1$ ) susceptible (S).

The present results with the susceptibility of mountain thyme, $P$. amboinicus to $M$. incognita did not differ with the findings of Maciel and Ferraz ( 1996) who reported the susceptibility of $P$. barbatus to $M$. incognita and $M$. javanica.

On the other hand, periwinkle, Catharanthus roseus was found to be resistant to $M$. incognita in which reproduction factor was less than one and plant growth was unaffected. This result is in accordance with those reported by Gandarilla et al., (1991) and McSorley and Frederick, (2001) in respect to M. incognita on C. roseus and William, (2003) who reported that $C$. roseus was poor or non- preferable host to $M$. incognita. However, the present results indicated that rose geranium Pelargonium odoratissimum was rated as moderately intolerant (IT) with RF $<1$ and plant growth was moderately affected. These findings disagreed with those of El-Derriny (2009) in respect to rose geranium that was found to be resistant to $M$. incognita.

\section{REFERENCES}

Byrd, D. W. ; Kirkpatrick, T. and Barker, K. (1983). An improved technique for clearing and staining plant tissues for detection of nematodes. $\mathrm{J}$. Nematol., 15(3):142-143. 
Canto-Saenz, M. (1983). The nature of resistance to Meloidogyne incognita (Kofoid \& White 1919) Chitwood 1949, pp. 160-165 In Proc. Third Res. \& Plann. Conf. on Root-knot Nematodes, Meloidogyne spp.,March 2226, 1982, ed. C. C. Carter. International Meloidogyne Project, Lima, Peru. $233 \mathrm{pp}$.

Cho, M. R.; Kim, J. Y.; Song, C.; Ko, J. Y.; Na, S. Y. and Yiem, M. S. (1996). Screening of carnation cultivars for resistance to Meloidogyne incognita. Suppl. J. Nematol. 28(4S): 639-642.

Duncan, D. B. (1955). Multiple range and multiple F. test. Biometrics 11, 1 42.

El-Deriny , Marwa, M. (2009). Studies on certain nematode pests parasitizing some ornamental plants. M. Sci Thesis, Agric. Dept., Agric. Fac. Mans. Univ. $122 \mathrm{pp}$.

Fernandez, E.; Carrasco, J.; Perez, J. and Acosta, M. (1991). Susceptibility of various species of flowers and ornamentals to Meloidogyne incognita race 2. Proteccion de Plantas.1(2): 7-14.

Ferris, H. (1992). Beyond Pesticides-Biological Approaches to Management in California. http://plpnemweb.ucdavis.edu/nemaplex/Mangmnt/ HPResist.htm, Rev. 12 Feb. 2004.

Gandarilla, H.; Kindelan, A. and Fernandez, E. (1991). Behaviour of five species of medicinal plants towards Meloidogyne incognita. Proteccion de Plantas. 1(1): 67-74.

Gomez, K. A. and Gomez, A. A. (1984). Statistical procedures for Agricultural Research.2 ${ }^{\text {nd }}$ Ed., John Wiley\&Sons: Inc., New York.

Goodey, J. B. (1957). Laboratory methods for work with plant and soil nematodes. Tech. Bull. No.2 Min. Agric. Fish Ed. London pp.47.

Johnson, S. B. N.; Cannayane, I. and Rajendran, G. (2003). Studies on the pathogenic level of Meloidogyne incognita on Gladiolus and Carnation. Current Nematol. 14(1/2): 75-78.

Khanna, A. S. and Jyoti, J. (2004). Pathogenicity of Meloidogyne incognita on Dianthus caryophyllus. Nematologia Mediterranea. 32(1): 125-126.

Maciel, S. L. and Ferraz, L. C. C. B. (1996). Reproduction rate of Meloidogyne incognita race 2 and Meloidogyne javanica in eight medicinal plant species. Scientia Agricola. 53(2/3): 232-236.

McSorley, R. and Frederick, J. J. (2001). Host suitability of some vinca and salvia cultivars to two isolates of root-knot nematodes. Proceedings of the Florida State Horticultural Society. 114: 239-241.

Oka, Y.; S. Necar; E. Putievesky; V. Ravid; Z. Yaniv and Y. Spiegel (2000). Nematicidal activity of essential oils and their components against the root-knot nematode. J. Phytopathol., 90(7): 710-715.

Taylor, A. L. and Sasser, J. N. (1978). Biology, identification and control of root-knot nematodes (Meloidogyne species). Raleigh North Carolina State Univ. Graphics, $111 \mathrm{pp}$.

Walker, J. T.; Melin, J. B. and Davis, J. (1994). Sensitivity of bedding plants to southern root-knot nematode, Meloidogyne incognita race 3 . J. Nematol. 26(4 S): 778-781. 
El-Sherif, A. G. et al.

Wang, K. H. and McSorley, R. (2005). Host status of several cut flower crops to the root-knot nematode, Meloidogyne incognita. Nematropica . 35(1): 45-52.

William, T. Crow. (2003). Nematode management for bedding plants.(http://edis.ifas.ufl.edu/IN470).

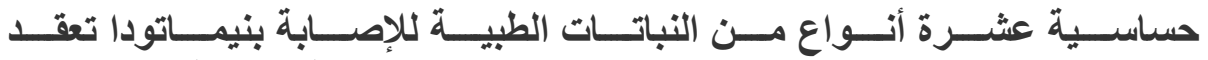
الجذورMeloidogyne incognita تحت ظروف الصوبة السلكية

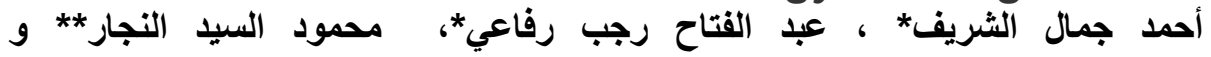

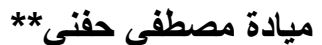
* وحدة بحوثُ النيمـاتولوجي ـ قـم الحيوان الزراعي ـ كلية الزراعة - جامعة المنصورة ـ ** معهد بحوث وقاية النباتات ـ مركز البحوث الزراعية ـ وزارة الزراعة ـ الدقي ـ الجيزة

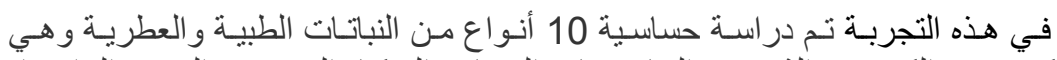

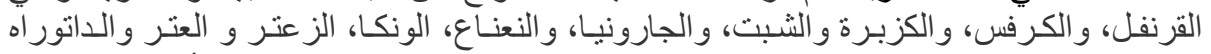

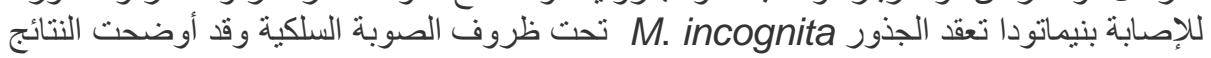

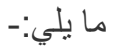

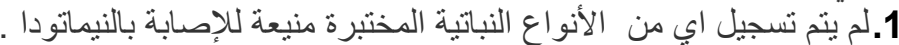

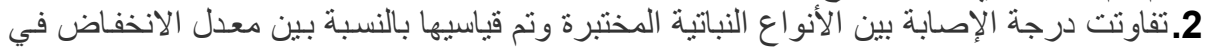

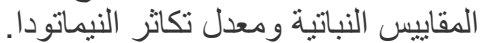

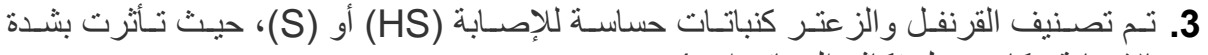

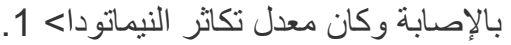

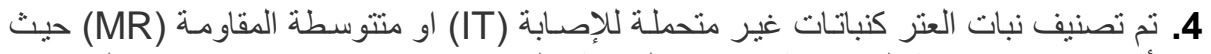

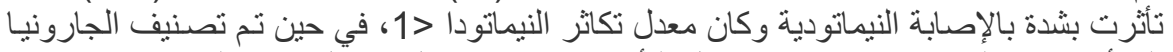

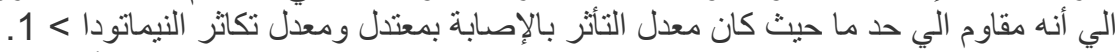

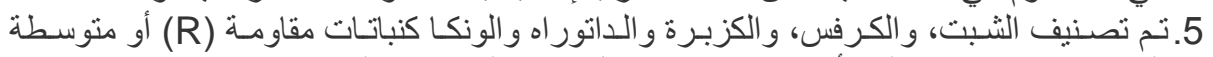

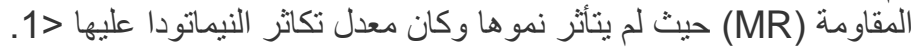

كلية الزراعة - جامعة المنصورة كلية الزراعة - جامعة القاهره
قام بتحكيم البحث

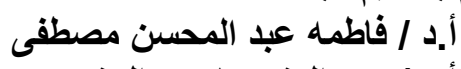
أ.د / عبد المنعم ياسين الجندى المعلى 
J. Plant Prot. and Path., Mansoura Univ., Vol. 3 (7), July, 2012 
El-Sherif, A. G. et al. 
Table (1): Plant growth of ten medicinal plant species as influenced by Meloidogyne incognita infection under greenhouse conditions $\left(28 \pm 3^{\circ} \mathrm{C}\right)$.

\begin{tabular}{|c|c|c|c|c|c|c|c|c|c|c|}
\hline \multirow{3}{*}{ Treatments } & \multicolumn{10}{|c|}{${ }^{*}$ Plant growth response } \\
\hline & \multicolumn{2}{|c|}{ Length $(\mathrm{cm})$} & \multirow[b]{2}{*}{ Total length } & \multirow{2}{*}{$\underset{* *}{\%}$} & \multicolumn{2}{|c|}{ Fresh weight (g) } & \multirow{2}{*}{$\begin{array}{c}\text { Fresh weight } \\
\text { of whole } \\
\text { plant }\end{array}$} & \multirow{2}{*}{$\begin{array}{c}\% \\
\text { Red } \\
* *\end{array}$} & \multirow{2}{*}{$\begin{array}{l}\text { Shoot dry } \\
\text { weight (g) }\end{array}$} & \multirow{2}{*}{$\underset{* *}{\%}$} \\
\hline & Shoot & Root & & & Shoot & Root & & & & \\
\hline Dill $+\mathrm{N}$ & $15 \mathrm{hi}$ & $3.0 \mathrm{~h}$ & $18.0 \mathrm{f}$ & 7.7 & $12.0 \mathrm{f}$ & $\begin{array}{c}2.5 \\
\text { def }\end{array}$ & 14.5 def & 9.4 & $1.7 \mathrm{fg}$ & 15.0 \\
\hline Dill (ck) & $16 \mathrm{hi}$ & $3.5 \mathrm{gh}$ & $19.5 \mathrm{f}$ & -- & $13.0 \mathrm{f}$ & $3.0 \mathrm{def}$ & 16.0 cdef & $\begin{array}{l}0.7 \\
--\end{array}$ & 2.0 efg &.--- \\
\hline Celery $+\mathrm{N}$ & $20 \mathrm{~g}$ & 6.9 efg & $26.9 \mathrm{e}$ & 11.2 & $19.0 \mathrm{~cd}$ & 3.3 def & 22.3 cdef & 5.1 & $4.5 \mathrm{bc}$ & 4.3 \\
\hline \begin{tabular}{|l} 
Celery (ck) \\
\end{tabular} & $22.3 \mathrm{fg}$ & 8.0 efg & $30.3 \mathrm{e}$ & -- & $19.5 \mathrm{~cd}$ & 4.0def & 23.5 bcdef & -- & $4.7 \mathrm{bc}$ & -- \\
\hline Coriander + N & $9.0 \mathrm{j}$ & $2.5 \mathrm{~h}$ & $11.5 \mathrm{~g}$ & 8.0 & 4.0 def & 1.5 ef & 5.5 def & 15.4 & $0.9 \mathrm{~g}$ & 10.0 \\
\hline Coriander (ck) & $9.5 j$ & $3.0 \mathrm{~h}$ & $12.5 \mathrm{~g}$ & -- & $4.5 \mathrm{de}$ & 2.0def & $6.5 \mathrm{def}$ & -- & $1.0 \mathrm{fg}$ & -- \\
\hline Carnation + N & $22.5 \mathrm{fg}$ & $24.0 \mathrm{ab}$ & $46.5 \mathrm{c}$ & 5.1 & 7.5 ef & $1.7 \mathrm{f}$ & $9.2 \mathrm{f}$ & 35.2 & 2.8 cdefg & 44.0 \\
\hline Carnation (ck) & 24.0 efg & $25.0 \mathrm{ab}$ & $49.0 \mathrm{bc}$ & -- & 12.7 def & 1.5 ef & 14.2 def & -- & $5.0 \mathrm{~b}$ & -- \\
\hline Peppermint $+\mathrm{N}$ & $30.3 \mathrm{~cd}$ & $24.0 \mathrm{ab}$ & $54.3 \mathrm{ab}$ & 7.2 & $35.5 \mathrm{a}$ & $21.8 \mathrm{~b}$ & $57.3 \mathrm{a}$ & 4.2 & $13.5 \mathrm{a}$ & 6.9 \\
\hline Peppermint (ck) & $34.5 \mathrm{bc}$ & $24.0 \mathrm{ab}$ & $58.5 \mathrm{a}$ & -- & $36.05 \mathrm{a}$ & $23.75 a$ & $59.8 a$ & & $14.5 \mathrm{a}$ & -- \\
\hline Thyme $+\mathrm{N}$ & $18.0 \mathrm{ghi}$ & 8.0 efg & $26.0 \mathrm{e}$ & 5.5 & $12.5 \mathrm{f}$ & $3.7 \mathrm{def}$ & 16.2 def & 47.1 & $1.5 \mathrm{fg}$ & 60.5 \\
\hline Thyme (ck) & $18.5 \mathrm{gh}$ & $9.0 \mathrm{def}$ & $27 . .5 \mathrm{e}$ & $\begin{array}{l}- \\
\end{array}$ & $25.0 \mathrm{~b}$ & $5.0 \mathrm{~d}$ & $30.6 \mathrm{bc}$ & -- & $3.8 \mathrm{~cd}$ & -- \\
\hline Geranium + N & $22.5 \mathrm{fg}$ & $27.0 \mathrm{a}$ & $49.5 \mathrm{bc}$ & 4.8 & $23.5 b c$ & 2.5 def & $26.0 \mathrm{bcde}$ & 17.2 & 2.7 cdefg & 6.9 \\
\hline Geranium (ck) & 24.0 efg & $28.0 \mathrm{a}$ & $52.0 \mathrm{abc}$ & -- & $28.5 \mathrm{~b}$ & 2.9 def & $31.4 \mathrm{bc}$ & -- & 2.9 cdefg & -- \\
\hline Thorne apple $+\mathrm{N}$ & $14.3 \mathrm{i}$ & $11.0 \mathrm{de}$ & $25.3 \mathrm{e}$ & 3.8 & $5.5 d$ & $5.1 d$ & 10.6 def & 7.8 & $1.4 \mathrm{fg}$ & 6.7 \\
\hline Thorne apple (ck) & $14.8 \mathrm{hi}$ & $11.5 \mathrm{~d}$ & $26.3 \mathrm{e}$ & $\begin{array}{l}- \\
\end{array}$ & $6.2 \mathrm{~g}$ & $5.3 d$ & 11.5 def & -- & $1.5 \mathrm{fg}$ & -- \\
\hline Periwinkle + N & $36.0 \mathrm{ab}$ & $18.0 \mathrm{c}$ & $54.0 \mathrm{ab}$ & 8.5 & $22.0 \mathrm{c}$ & $15.5 \mathrm{c}$ & $37.5 \mathrm{~b}$ & 2.6 & $3.4 \mathrm{~cd}$ & 8.1 \\
\hline Periwinkle (ck) & $38.0 \mathrm{a}$ & $21.0 \mathrm{~b}$ & $59.0 \mathrm{a}$ & -- & $22.5 \mathrm{c}$ & $16.0 \mathrm{c}$ & $38.5 \mathrm{~b}$ & -- & $3.7 \mathrm{~cd}$ & -- \\
\hline Rose geranium + N & 26.0 ef & $24.0 \mathrm{ab}$ & $50.0 \mathrm{bc}$ & 9.1 & $16.0 \mathrm{e}$ & 3.0 def & 19.0 cdef & 10.8 & $3.0 \mathrm{cde}$ & 18.9 \\
\hline Rose geranium (ck) & 30.0 def & $25.0 \mathrm{ab}$ & $55.0 \mathrm{ab}$ & --- & $18.0 \mathrm{~d}$ & 3.3 def & $21.3 \mathrm{cdef}$ & -- & $3.7 \mathrm{~cd}$ & -- \\
\hline
\end{tabular}

$\mathrm{N}=1000 \mathrm{~J} 2$ of $M$. incognita

*Each value is a mean of three replicates.

Means in each column followed by the same letter(s) did not differ at $p<0.05$ according to Duncan's multiple-range test.

Ck= non-inoculated. 